\title{
Bipotential Glial Precursor Cells of the Optic Nerve Express the NG2 Proteoglycan
}

\author{
William B. Stallcup and Lora Beasley \\ Cancer Research Center, La Jolla Cancer Research Foundation, La Jolla, California 92037
}

\begin{abstract}
We have studied the expression of the NG2 chondroitin sulfate proteoglycan on bipotential glial precursor cells in cultures of postnatal rat optic nerve. Purified populations of these precursor cells were prepared by panning dissociated optic nerve cells on dishes coated with monoclonal $A_{2} B_{5}$ antibody. Using immunofluorescence double staining, we found that NG2 was present on almost $95 \%$ of the purified $A_{2} B_{6}{ }^{+}$precursor cells. The NG2 core protein from optic nerve cells was identified by immune precipitation and PAGE and was found to be identical to the $300,000 \mathrm{Da}$ NG2 core protein from a clonal rat cell line B49. Over a culture period of $5 \mathrm{~d}$ in medium containing $10 \%$ fetal calf serum, more than $80 \%$ of the NG2 ' precursor cells acquired the glial fibrillary acidic protein (GFAP), an astrocyte-specific marker. Under these conditions, fewer than $10 \%$ of the $\mathrm{NG2}^{+}$cells expressed galactocerebroside (GC), an oligodendrocyte-specific marker. These GFAP GC type II astrocytes continued to express the NG2 antigen for up to $10 \mathrm{~d}$ in culture. During a $5 \mathrm{~d}$ culture period in hormonally supplemented, serum-free medium, fewer than $15 \%$ of the $\mathrm{NG2}^{+}$cells expressed GFAP, while up to $40 \%$ expressed GC. The NG2 antigen continued to be expressed for only a short period of time by these GFAP-GC+ oligodendrocytes, so that mature oligodendrocytes in the cultures became NG2 - These results support our previous suggestion that the NG2 antigen is found on a class of neural cells that can differentiate along more than one pathway.
\end{abstract}

The question of how and when cells become committed to particular lineages is one of the key problems of developmental neurobiology. The analysis of this problem is aided considerably by the use of antibodies that recognize antigens expressed by a particular class of cell or at a particular stage of cellular development. In previous reports, we have suggested that the NG2 antigen can be useful for the study of certain cell lineages in the developing rat nervous system. The NG2 antigen was initially defined in terms of its expression on a few rat neural cell lines that exhibited properties characteristic of both nerve and glial cells (Wilson et al., 1981). Subsequently we have shown that the NG2 molecule from these cell lines is a chondroitin sulfate proteoglycan of roughly $500,000 \mathrm{Da}$ with a core glycoprotein of 300,000 Da (Stallcup et al., 1984). By immunohistochemical means, NG2 has been localized to populations of stellate-shaped cells in primary cultures of embryonic brain and postnatal cer-

\footnotetext{
Received Oct. 13, 1986; revised Feb. 23, 1987; accepted Feb. 26, 1987.

This work was supported by NIH Grant NS 21990 to W.B.S.

Correspondence should be addressed to William B. Stalicup, Ia Jolla Cancer

Research Foundation, 10901 North Torrey Pines Road, La Jolla, CA 92037.

Copyright $(\mathcal{C} 1987$ Society for Neuroscience 0270-6474/87/092737-08\$02.00/0
}

ebellum (Stallcup, 1981), as well as in frozen sections of developing and mature rat brain (Stallcup et al., 1984). The most recent electron microscopic evidence now indicates that NG2positive cells in the molecular layer of the adult rat cerebellar cortex may be smooth protoplasmic astrocytes containing few glial filaments (Levine and Card, 1987). However, in vitro studies with early postnatal cerebellum show that NG2-positive cells may not be locked into this lineage but can display a degree of phenotypic plasticity in response to environmental conditions (Levine and Stallcup, 1987). In serum-free medium, NG2-positive cells express neither the glial fibrillary acidic protein (GFAP), an astrocyte-specific marker (Bignami et al., 1972), nor galactocerebroside (GC), an oligodendrocyte-specific marker (Raff ct al., 1978). These cells thus resemble the smooth protoplasmic astrocytes seen in vivo. However, in the presence of fetal calf serum, NG2-bearing cells acquire GFAP and appear to be equivalent to type II astrocytes.

The stellate morphology of cerebellar NG2-bearing cells, their ability to bind tetanus toxin and $\mathrm{A}_{2} \mathrm{~B}_{5}$ antibody (Stallcup, 1981; Levine and Stallcup, 1987), and their phenolypic plasticity in vitro are highly reminiscent of the bipotential glial precursor cells identified by Raff and coworkers in the rat optic nerve. Three types of glial cells have been identified in optic nerve cultures: type I astrocytes, which are GFAP ${ }^{+} \mathrm{A}_{2} \mathrm{~B}_{5}^{-}$; type II astrocytes, which are GFAP ${ }^{+} \mathrm{A}_{2} \mathrm{~B}_{5}{ }^{+}$; and oligodendrocytes, which are $\mathrm{GC}^{+} \mathrm{A}_{2} \mathrm{~B}_{5}{ }^{+}$(Raff et al., 1983a, b). Type I and II astrocytes in vitro are thought to correspond to protoplasmic and fibrous astrocytes in vivo, respectively (Miller and Raff, 1984). Oligodendrocytes and type II astrocytes have been shown to arise in vitro from a common precursor cell with the phenotype $\mathrm{A}_{2} \mathrm{~B}_{5}{ }^{+} \mathrm{GFAP}^{-} \mathrm{GC}^{-}$. This bipotential precursor gives rise to type II astrocytes in the presence of fetal calf serum and to oligodendrocytes in serum-free, defined medium (Raff et al., 1983b, 1984).

Since the NG2-bearing cells in our cerebellar cultures appear to be similar to the $\mathrm{A}_{2} \mathrm{~B}_{5}{ }^{+}$bipotential precursor cells in optic nerve, and since the optic nerve is at present the definitive system for identifying these precursor cells, we have examined the expression of NG2 by optic nerve cells in culture. Our results show that the NG2 and $A_{2} B_{5}$ markers are coexpressed by the glial precursor cells in these cultures and suggest that NG2bearing cells in optic nerve and cerebellar cultures may not behave in identical fashion.

\section{Materials and Methods}

Cell culture. The B49 cell line (Schubert et al., 1974) was maintained in Dulbecco's Modified Eagle's Medium (DMEM) containing 10\% fetal calf serum (Tissue Culture Biologicals). Primary cultures of optic nerve were prepared from 6-d-old Sprague-Dawley rat pups. Optic nerves were 
Table 1. Phenotypic plasticity of purified optic nerve cells

\begin{tabular}{|c|c|c|c|c|c|}
\hline & \multirow[b]{2}{*}{ Phenotype } & \multicolumn{4}{|c|}{ Days in culture $(\%)$} \\
\hline & & 2 & 3 & 4 & 5 \\
\hline & $\mathrm{NG}^{2}{ }^{+}$cells & & & & \\
\hline In & $\mathrm{GFAP}^{+}(\%)$ & 10 & 46 & 79 & 88 \\
\hline \multirow[t]{8}{*}{ serum } & $\mathrm{GC}^{+}(\%)$ & 3 & 6 & 5 & 8 \\
\hline & $\mathrm{A}_{2} \mathrm{~B}_{5}{ }^{+}$cells & & & & \\
\hline & $\mathrm{NG}_{2}+(\%)$ & 91 & 97 & 92 & 96 \\
\hline & $\mathrm{GFAP}^{+}(\%)$ & 12 & 38 & 77 & 79 \\
\hline & $\mathrm{GC}^{+}(\%)$ & 4 & 3 & 4 & 9 \\
\hline & Stellate cells & & & & \\
\hline & $\mathrm{NG}^{+}(\%)$ & 91 & 95 & 93 & 87 \\
\hline & $\mathrm{NG}_{2}{ }^{+}$cells & & & & \\
\hline \multirow{7}{*}{$\begin{array}{l}\text { Without } \\
\text { serum }\end{array}$} & $\mathrm{GFAP}^{+}(\%)$ & 6 & 9 & 12 & 15 \\
\hline & $\mathrm{GC}^{+}(\%)$ & 5 & 19 & 36 & 38 \\
\hline & $\mathrm{A}_{2} \mathrm{~B}_{5}{ }^{+}$cells & & & & \\
\hline & $\mathrm{GFAP}^{+}(\%)$ & 8 & 13 & 10 & 13 \\
\hline & $\mathrm{GC}^{+}(\%)$ & 9 & 25 & 55 & 59 \\
\hline & Stellate cells & & & & \\
\hline & $\mathrm{NG}_{2}+(\%)$ & 86 & 74 & 51 & 34 \\
\hline
\end{tabular}

Values represent the percentage of $\mathrm{NG}^{+}$or $\mathrm{A}_{2} \mathrm{~B}_{5}{ }^{+}$cells that are also positive for GFAP or GC. This was determined by immunofluorescence double-staining. Phase contrast and immunofluorescence were used to determine the percentage of stellate cells that were NG2+. In all cases, at least 100 cells were scored. Rather than score replicate plates within one experiment, we elected to repeat these experiments 3 times. The pattern of GFAP acquisition-NG2 retention in serum and GC acquisition-NG2 loss in the absence of serum was clearly reproduced in these 3 independent sets of cultures. Table 1 is not an average of these 3 trials but presents the complete results obtained from 1 of the 3 sets of cultures.

removed from decapitated pups and incubated for $30 \mathrm{~min}$ at $37^{\circ} \mathrm{C}$ in 2 $\mathrm{ml}$ of $\mathrm{Ca}^{2+}-\mathrm{Mg}^{2+}$-free HEPES-buffered DMEM containing $0.1 \%$ trypsin and $0.1 \%$ collagenase (Sigma). The tissue was then dispersed by trituration with a Pasteur pipet and incubated at $37^{\circ} \mathrm{C}$ for an additional 30 min. Following the addition of $2 \mathrm{ml}$ of DMEM containing $10 \%$ fetal calf serum, the tissue was again dispersed by pipetting, and any undissociated pieces were allowed to settle. The dissociated cells remaining in suspension were then removed and washed 3 times with DMEM containing $10 \%$ fetal calf serum.

The dissociated optic nerve cells recovered from this procedure were subjected to panning on dishes coated with $\mathrm{A}_{2} \mathrm{~B}_{5}$ monoclonal antibody (Eisenbarth et al., 1979). The panning dishes were prepared as described by Danielsen et al. (1983). Briefly, $100 \mathrm{~mm}$ petri dishes (Falcon) were allowed to stand overnight at $4^{\circ} \mathrm{C}$ with $0.02 \mathrm{M}$ Tris- $\mathrm{Cl}, \mathrm{pH} 9.5$, containing $20 \mu \mathrm{g} / \mathrm{ml}$ of an IgG fraction prepared by ammonium sulfate precipitation from $\mathrm{A}_{2} \mathrm{~B}_{5}$ ascites fluid. Under these conditions some of the antibody bound nonspecifically to the plastic dishes. Coated dishes were washed 3 times with HEPES-buffered DMEM, followed by incubation for $4 \mathrm{hr}$ with HEPES-buffered DMEM containing $1 \%$ fetal calf serum to block remaining nonspecific binding sites. After replacing the blocking solution with $6 \mathrm{ml} /$ dish of fresh HEPES-buffered DMEM containing $1 \%$ fetal calf serum, the optic nerve cell suspension was added to the dishes and allowed to remain undisturbed at $4^{\circ} \mathrm{C}$ for $1 \mathrm{hr}$. Typically, 3 dishes were used for panning the cell suspension obtained from an average litter of 12-14 pups. The dishes were gently swirled, and unbound cells were removed by aspiration. In some cases, these unbound cells were saved and put into culture for comparison with bound cells. Following 2 gentle washes to remove any remaining unbound cells, the bound cells were detached from the dishes by pipetting and transferred to a single fresh $A_{2} B_{5}$-coated dish for a second round of panning. Bound cells from this second panning were again detached by pipetting and harvested by centrifugation.

The $\mathrm{A}_{2} \mathrm{~B}_{5}$-panned cells were resuspended in $1 \mathrm{ml}$ HEPES-buffered DMEM containing $1 \%$ fetal calf serum, rabbit antibody against GC at a 1:50 dilution (gift of Dr. R. Milner) and guinea pig complement at a $1: 10$ dilution (GIBCO). Incubation at $37^{\circ} \mathrm{C}$ for $1 \mathrm{hr}$ effectively killed GC-positive cells in the suspension. A second round of cytotoxic killing did not appreciably improve the killing efficiency. The resulting $\mathrm{A}_{2} \mathrm{~B}_{5}$ - panned, anti-GC-killed cells were washed twice in DMEM plus 10\% fetal calf serum, resuspended in this same medium, and plated on 35 $\mathrm{mm}$ tissue culture dishes (Falcon) coated with poly(L-lysine) (Sigma). Cells were allowed $15 \mathrm{hr}$ to attach and recover from the isolation procedures. They were then fed with DMEM plus $10 \%$ fetal calf serum or washed with DMEM and switched to a serum-free, hormonally defined medium. This medium consisted of a 50:50 mixture of DMEM and Ham's F12 medium and contained insulin, transferrin, progesterone, putrescine, and selenium in place of serum (Bottenstein and Sato, 1979). Total days in vitro were measured from the initial time of plating the cells.

Immunofluorescence. Immunofluorescent labeling of the cultures was performed essentially as described previously (Stallcup, 1981; Stallcup et al., 1984). Double staining for the NG2 and $A_{2} B_{5}$ markers was accomplished using a guinea pig anti-NG2 antibody and a mouse monoclonal $A_{2} B_{5}$ ascites preparation. Rhodamine-labelled goat antibody against guinea pig immunoglobulin (R-GaGPIg, prepared in our laboratory) and fluorescein-labeled goat antibody against mouse immunoglobulin (F-GaMIg) served as secondary antibodies in this case. Comparison of NG2 with the GC or GFAP markers was performed using guinea pig antibody against $\mathrm{NG} 2$ and rabbit antibodies against either GC or GFAP (Accurate Chemical). R-GaGPIg and fluorescein-labeled goat antibody against rabbit immunoglobulin ( $\mathrm{F}-\mathrm{GaRIg})$ were used as second antibodies for these experiments. When $\mathrm{A}_{2} \mathrm{~B}_{5}$ antibody was compared with anti-GC or anti-GFAP, R-GaMIg and F-GaRIg served as second antibodies. Except in the case of anti-GFAP, all staining was performed on live cells. Prior to staining with anti-GFAP, cells were fixed in $95 \%$ ethanol at $-20^{\circ} \mathrm{C}$ for 10 min due to the intracellular location of the antigen.

A Nikon Optiphot microscope equipped for fluorescein and rhodamine epifluorescence was used to examine the stained cultures. At least $100 \mathrm{NG}^{+}$or $\mathrm{A}_{2} \mathrm{~B}_{5}{ }^{+}$cells were scored in the case of each of the comparisons presented in Table 1. Kodak Tri-X 400 film was used for the photography.

Immunoprecipitation and electrophoresis. B49 cells and primary optic nerve cultures were surface-labeled with ${ }^{125}$ ( Amersham) using the lactoperoxidase method (Hubbard and Cohn, 1972). Iodinated cells were washed 4 times with PBS, harvested, and extracted using $0.5 \mathrm{ml}$ of $1 \%$ Nonidet P-40 (NP-40) in PBS, containing $1 \mathrm{mM} \mathrm{PMSF}$ (Cal Biochem) to inhibit proteolysis. Insoluble material was removed after $10 \mathrm{~min}$ by centrifugation, and the resulting supernatant was used for preparing immune precipitates. Samples of extract, $200 \mu 1$, were incubated with $10 \mu \mathrm{l}$ rabbit antibody against NG2 for $1 \mathrm{hr}$, followed by addition of 30 $\mu$ l goat antibody against rabbit immunoglobulin to effect immunoprecipitation. As a control, some samples of extract were incubated with primary antibody that had been absorbed with B49 cells to remove antiNG2 activity. Precipitates were washed 3 times with PBS, dissolved in electrophoresis sample buffer containing 3\% SDS and 5\% mercaptoethanol, and subjected to PAGE on 3-20\% polyacrylamide gradient gels (Laemmli, 1970). Gels were dried, and immunoprecipitated components were identified on autoradiograms prepared using Kodak XAR-5 film and Cronex intensifying screens.

\section{Results and Discussion}

The stellate morphology of $\mathrm{NG} 2^{+}$cells in rat cerebellar cultures, their capacity to be labeled with $\mathrm{A}_{2} \mathrm{~B}_{5}$ antibody and with tetanus toxin, and their phenotypic plasticity are characteristics very similar to those described by Raff and coworkers for bipotential glial precursor cells in cultures of rat optic nerve. The experiments reported here provide a direct comparison of the expression of the $\mathrm{NG} 2$ and $\mathrm{A}_{2} \mathrm{~B}_{5}$ markers by the bipotential glial precursor cells of the optic nerve. For this comparison, we prepared purified cultures of the precursor cells using a cell-panning technique. Because the NG2 molecule is highly sensitive to the trypsinization procedure used to dissociate the tissue, NG2 cannot be effectively utilized as the basis for panning freshly dissociated cells. However, the gangliosides recognized by $\mathrm{A}_{2} \mathrm{~B}_{5}$ antibody (Kasai and $\mathrm{Yu}, 1983$; Kundu et al., 1983) are resistant to trypsin treatment, and $\mathrm{A}_{2} \mathrm{~B}_{5}$-coated dishes can be used to separate $\mathrm{A}_{2} \mathrm{~B}_{5}{ }^{+}$cells from $\mathrm{A}_{2} \mathrm{~B}_{5}{ }^{-}$cells. Although very few of these $\mathrm{A}_{2} \mathrm{~B}_{5}{ }^{+}$cells express GFAP at the time of dissociation, a signif- 

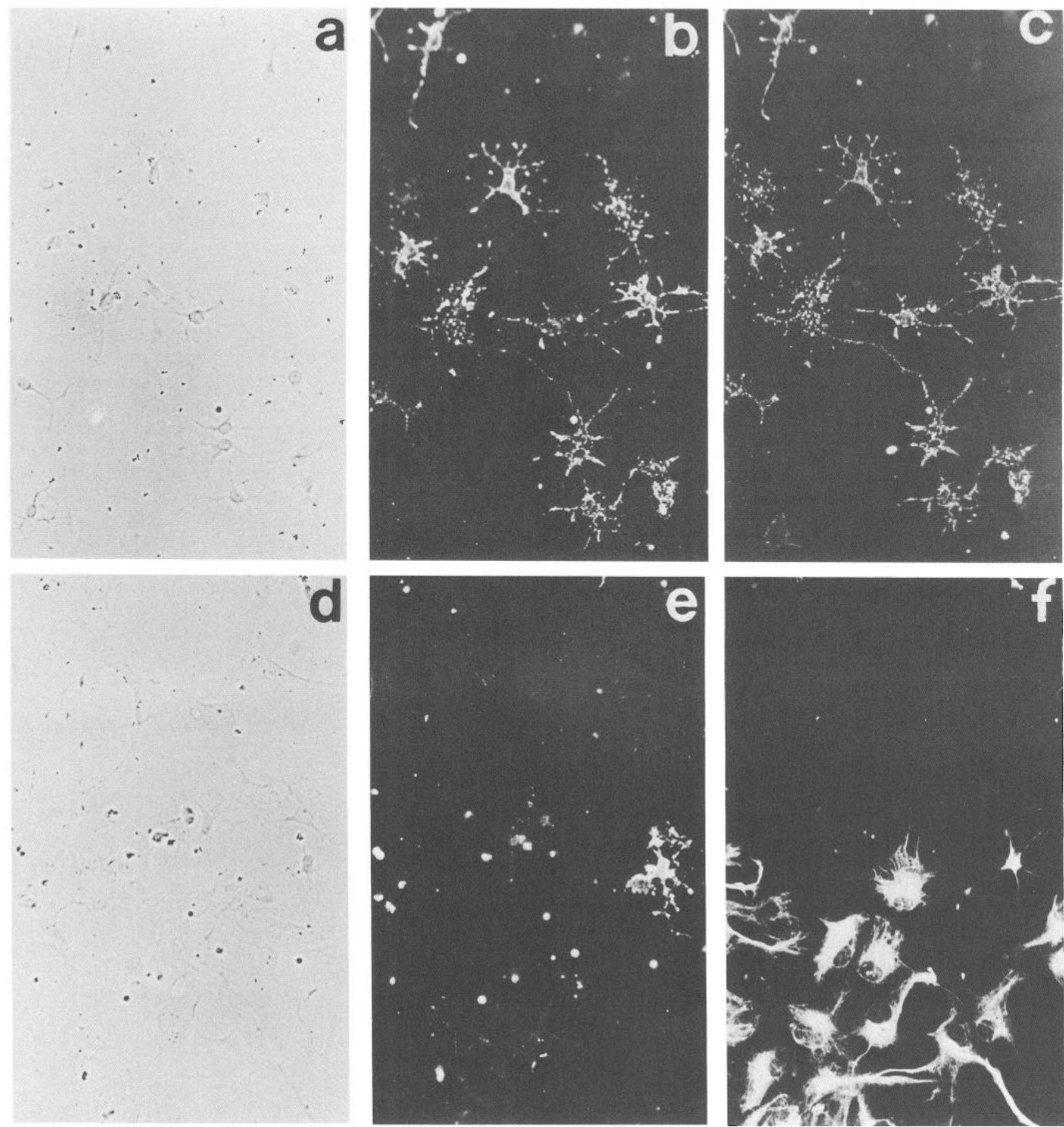

Figure 1. Anti-NG2 and anti- $\mathrm{A}_{2} \mathrm{~B}_{5}$ antibodies label the same cells in optic nerve cultures. $a-c, \mathrm{~A}_{2} \mathrm{~B}_{5}$-panned, anti-GC-killed optic nerve cells were double-stained for the NG2 and $\mathrm{A}_{2} \mathrm{~B}_{5}$ markers after $3 \mathrm{~d}$ in serum-containing medium. The 2 antibodies label the same cells in these purified cultures. $a$, Phase contrast; $b$, anti- $\mathrm{A}_{2} \mathrm{~B}_{5}$ (fluorescein optics); $c$, anti-NG2 (rhodamine optics). $d-f$, Cells that were not bound to $\mathrm{A}_{2} \mathrm{~B}_{5}$-coated dishes during the panning procedure were grown in culture for $3 \mathrm{~d}$ and double-stained for the $\mathrm{A}_{2} \mathrm{~B}_{5}$ and GFAP markers. The large majority of these cells were $\mathrm{A}_{2} \mathrm{~B}_{5}$-negative flat cells, many of which are GFAP ${ }^{+}$type I astrocytes. $a$, Phase contrast; $b$, anti- $\mathrm{A}_{2} \mathrm{~B}_{5}$ (rhodamine optics); $c$, anti-GFAP (fluorescein optics).

icant number express GC. To simplify interpretation of subsequent experiments, these $\mathrm{A}_{2} \mathrm{~B}_{5}{ }^{+} \mathrm{GC}^{+}$cells were killed with antiGC antibody and complement. The combination of cell panning and complement-mediated killing allowed us to begin our experiments with cell populations in which more than $90 \%$ of the cells had the phenotype $\mathrm{A}_{2} \mathrm{~B}_{5}{ }^{+} \mathrm{GFAP}-\mathrm{GC}^{-}$. The importance of using this purified population will become more apparent as the discussion progresses.

The morphology of the $\mathrm{A}_{2} \mathrm{~B}_{5}$-panned cells after $3 \mathrm{~d}$ of culture in serum-containing medium is shown in Figure $1 a$. Double- 


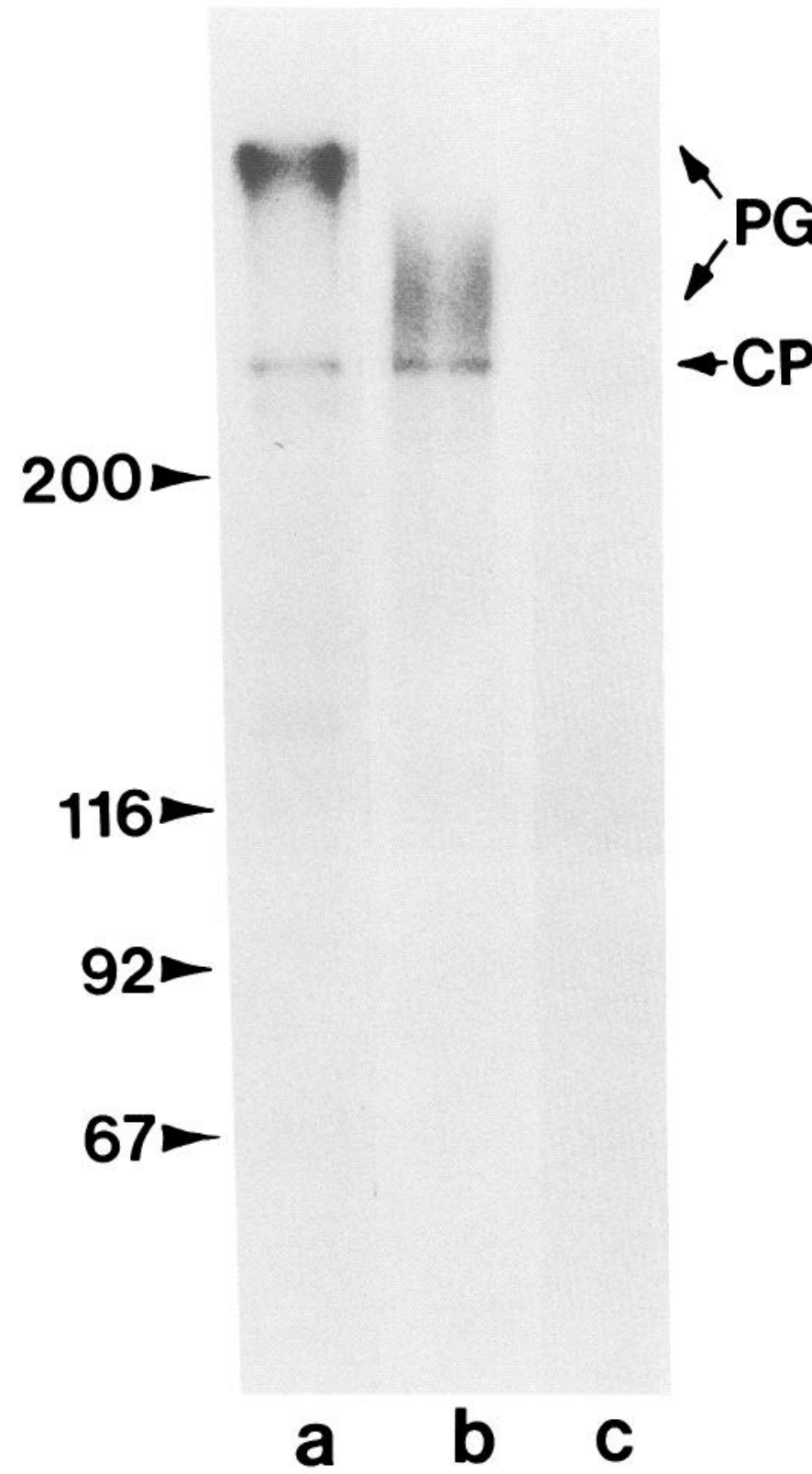

Figure 2. Identification of NG2 molecules on optic nerve and B49 cells. Material immunoprecipitated by anti-NG2 antibodies from detergent extracts of ${ }^{125}$ I-labeled cell cultures was analyzed by SDS-PAGE and autoradiography. NG2-immunoreactive material from B49 cells (lane $a$ ) and purified optic nerve cultures (lane $b$ ) contains indistinguishable core proteins $(C P)$ of about $300,000 \mathrm{Da}$ but different sized proteoglycans $(P G)$. Anti-NG2 preabsorbed with B49 cells does not immunoprecipitate either component from optic nerve cells (lane $c$ ). Molecular weight markers at left are in kilodaltons.

staining experiments showed that these stellate cells were positive for both $\mathrm{A}_{2} \mathrm{~B}_{5}$ (Fig. $1 b$ ) and NG2 (Fig. 1c). Cell counts from 4 separate sets of double-stained cultures indicated that $94 \pm$ $5 \%$ of $\mathrm{A}_{2} \mathrm{~B}_{5}{ }^{+}$cells in the purified population were positive for NG2 (Table 1). This confirms our initial speculation concerning the apparent similarities between $\mathrm{A}_{2} \mathrm{~B}_{5}{ }^{+}$and NG2 ${ }^{+}$cells. Cells that did not adhere to the $\mathrm{A}_{2} \mathrm{~B}_{5}$-coated dishes, and thus were not included in the purified cell population, had very different phenotypes, as shown in Figure $1, d-f$. A few of the stellate $\mathrm{A}_{2} \mathrm{~B}_{5}{ }^{+}$cells were found in these cultures (Fig. 1e), but the vast majority of cells had a flat morphology and were negative for $\mathrm{A}_{2} \mathrm{~B}_{5}$ (Fig. $1, d, e$ ). Some of these $\mathrm{A}_{2} \mathrm{~B}_{5}{ }^{-}$cells expressed GFAP (Fig. $1 f$ ) and were classified as type I astrocytes, while others were positive for fibronectin and were probably fibroblasts (not shown). Approximately a third of the fibronectin-positive cells were also positive for NG2. Eliminating these NG2+ fibroblasts from the cultures by means of cell panning was thus useful in avoiding confusion during examination of the properties of $\mathrm{NG}_{2}{ }^{+}$ cells of the stellate, $\mathrm{A}_{2} \mathrm{~B}_{5}{ }^{+}$type.

After surface labeling the purified optic nerve cultures with ${ }^{125} \mathrm{I}$, we used immunoprecipitation with anti-NG2 antibody to isolate the NG2-immunoreactive molecule from a detergent extract of the cells. SDS-PAGE was used to compare the immunoprecipitated material with the NG2 molecule expressed by the cloned B 49 cell line. Figure $2 a$ shows that 2 components were immunoprecipitated from B49 cells: (1) a smear in the molecular-weight range of 450,000-500,000 Da, and (2) a welldefined band of $300,000 \mathrm{Da}$. We have shown that these 2 components correspond, respectively, to a chondroitin sulfate proteoglycan (PG) and the core protein for this proteoglycan (CP) (Stallcup et al., 1984). Our antibody recognizes the CP rather than the chondroitin sulfate chains. In immune precipitates prepared from extracts of stellate optic nerve cells, we observed a core protein indistinguishable from that derived from B49 cells. However, the proteoglycan from the optic nerve cells was smaller and more polydisperse than that from B49 cells (Fig. $2 b$ ). No components were immunoprecipitated from the ${ }^{125} \mathrm{I}$-labeled optic nerve material when we used anti-NG2 antibody absorbed with B49 cells (Fig. 2c). Since the core protein of the B49-derived NG2 is identical in size to that of optic nerve-derived NG2, the difference between the size of the 2 proteoglycans must be due to the chondroitin sulfate portion of the molecules. Similar differences have been observed in the size of NG2 proteoglycans from several rat neural cell lines (Stallcup et al., 1984). These differences in size could be due to variability in the length and/ or the number of chondroitin sulfate chains attached to a common NG2 core protein.

Since $\mathrm{A}_{2} \mathrm{~B}_{5}{ }^{+} \mathrm{GFAP}^{-} \mathrm{GC}^{-}$precursor cells in optic nerve cultures can differentiate into either $\mathrm{A}_{2} \mathrm{~B}_{5}{ }^{+} \mathrm{GFAP}^{+} \mathrm{GC}^{-}$type II astrocytes or $\mathrm{A}_{2} \mathrm{~B}_{5}{ }^{+} \mathrm{GFAP}^{-} \mathrm{GC}^{+}$oligodendrocytes, depending on the presence or absence of fetal calf serum (Raff et al., 1983b, 1984), we determined the effect of serum-containing and serum-free defined media on the expression of the NG2 proteoglycan. Figure $3, b$ and $e$, shows that after $4 \mathrm{~d}$ in serum-containing medium, almost all of the stellate optic nerve cells were still positive for NG2. The majority of these $\mathrm{NG}^{2}{ }^{+}$cells had also acquired GFAP (Fig. $3 c$ ). Arrows in Figure $3, b$ and $c$, indicate rare $\mathrm{NG}^{+}$cells that had not yet expressed GFAP. In contrast, the $\mathrm{NG}^{+}$cells did not express the GC marker after $4 \mathrm{~d}$ in serum-containing medium (Fig. $3 f$ ). The upper half of Table 1 presents a more detailed accounting of the phenotype of $\mathrm{NG}^{+}$cells in serumcontaining cultures. The percentage of $\mathrm{NG}^{+}$cells expressing GFAP was initially low $(<10 \%)$ and increased to almost $90 \%$ after $5 \mathrm{~d}$ in culture. The GC marker was rarely expressed under these culture conditions ( $<10 \%$ of the $\mathrm{NG}^{+}$population). We can conclude that the $\mathrm{NG}^{+}{ }^{+} \mathrm{GFAP}^{+}$cells seen after several days in serum-containing medium were derived from NG2+GFAPprecursors and not from $\mathrm{NG}^{-} \mathrm{GFAP}^{+}$cells (type I astrocytes) or from $\mathrm{NG}^{+}{ }^{+} \mathrm{GFAP}^{-} \mathrm{FN}^{+}$cells (fibroblasts), since these 2 cell types were removed from the starting population during the purification of stellate $\mathrm{A}_{2} \mathrm{~B}_{5}+\mathrm{NG} 2+$ cells. Table 1 also shows the results of screening parallel sets of cultures for expression of 

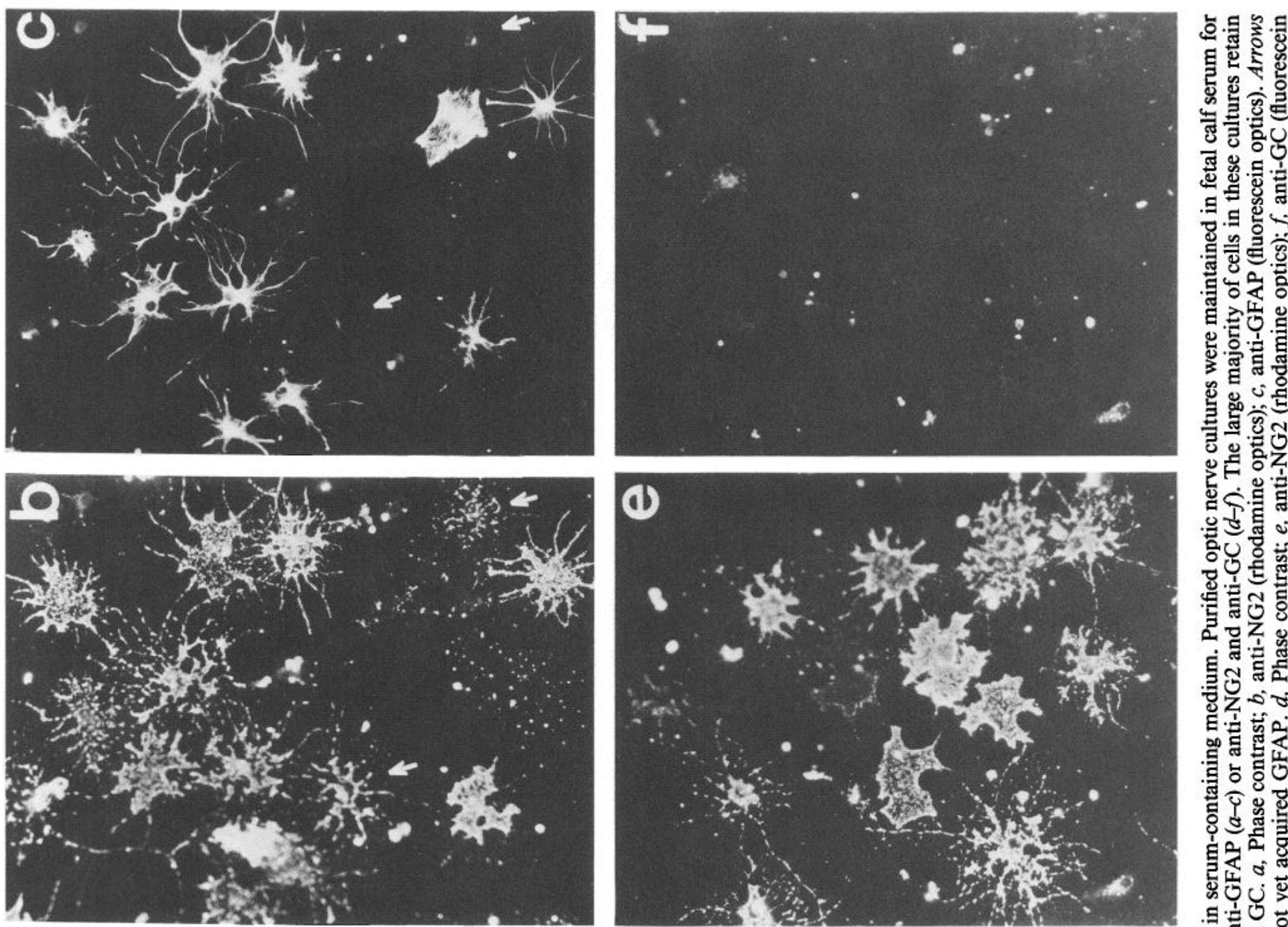

员

ㄷ․ㄹ . 엉응 놀 突 르 ह่ \%०० ह. on 녕 ज़이 워를 हैं है 和 車记 目光诺 है 40

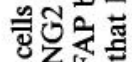
넌 蹗范 능 고을 ठิ 乙㐘

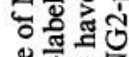
政 

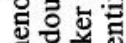

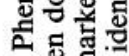
过

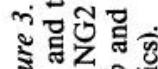

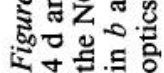


GFAP and GC by $\mathrm{A}_{2} \mathrm{~B}_{5}{ }^{+}$cells. Since Raff et al. $(1983 \mathrm{~b}, 1984)$ have clearly delineated the fate of $\mathrm{A}_{2} \mathrm{~B}_{5}{ }^{+}$precursor cells in culture and since $A_{2} B_{5}$ and NG2 were both found on the purified precursor cells, it is not surprising that the conversion of $\mathrm{A}_{2} \mathrm{~B}_{5}{ }^{+} \mathrm{GFAP}^{-} \mathrm{GC}^{-}$cells to $\mathrm{A}_{2} \mathrm{~B}_{5}{ }^{+} \mathrm{GFAP}^{+} \mathrm{GC}^{-}$cells closely paralleled the conversion of $\mathrm{NG}^{+}{ }^{+} \mathrm{GFAP}-\mathrm{GC}^{-}$cells to the $\mathrm{NG}^{+}{ }^{+} \mathrm{GFAP}^{+} \mathrm{GC}^{-}$phenotype. Thus, both the $\mathrm{A}_{2} \mathrm{~B}_{5}$ and NG2 markers were retained as the precursors differentiated into type II astrocytes. $\mathrm{A}_{2} \mathrm{~B}_{5}$ and $\mathrm{NG} 2$ continued to be expressed by GFAP ${ }^{+}$ type II astrocytes for at least $10 \mathrm{~d}$ in vitro, the latest time point we tested. The stability of NG2 expression in serum-containing medium is also reflected by the fact that $90 \%$ of stellate optic nerve cells (identified by phase-contrast microscopy) were positive for NG2 throughout the $5 \mathrm{~d}$ culture period (Table 1). This is consistent with our finding that $94 \%$ of $\mathrm{A}_{2} \mathrm{~B}_{5}{ }^{+}$cells are NG2+

In serum-free, defined medium, $\mathrm{NG}^{+}$cells had a somewhat different morphology than in serum-containing medium. In the absence of serum, the processes of $\mathrm{NG} 2^{+}$cells were finer, more numerous, and more branched than those in serum-containing medium (compare Fig. $4, b$, e, with $3, b, e$ ). Few of the $\mathrm{NG2}^{+}$ cells expressed GFAP after $4 \mathrm{~d}$ in defined medium (Fig. $4 c$ ), in direct contrast to what was observed in the presence of serum. Conversely, the proportion of $\mathrm{NG}^{+}$cells that expressed GC in defined medium was much greater than that seen in serumcontaining medium. Figure $4, e$ and $f$, shows 2 cells that were positive for both $\mathrm{NG} 2$ and $\mathrm{GC}\left(\mathrm{NG}^{+} \mathrm{GC}^{+}\right.$, indicated by small arrows). Another cell was weakly positive for NG2 and positive for $\mathrm{GC}$ (NG2 $\pm \mathrm{GC}^{+}$, large arrow). A fourth cell was strongly positive for $\mathrm{GC}$ and negative for $\mathrm{NG} 2\left(\mathrm{NG}^{-} \mathrm{GC}^{++}\right.$, asterisk). We consistently noted that $\mathrm{NG}_{2}{ }^{+} \mathrm{GC}^{+}$cells in these cultures were not labeled as brightly with anti-GC antibody as were the $\mathrm{NG} 2 \pm \mathrm{GC}^{+}$or $\mathrm{NG} 2-\mathrm{GC}^{++}$cells. In addition, the $\mathrm{NG}^{+} \mathrm{GC}^{+}$cells were less intensely stained with anti-NG2 than were $\mathrm{NG}_{2}+\mathrm{GC}^{-}$ cells. Table 1 gives a daily accounting of the expression of NG2, GFAP, and GC in serum-free medium, and it also presents the proportion of $\mathrm{A}_{2} \mathrm{~B}_{5}{ }^{+}$cells that expressed GFAP or GC in parallel sets of cultures. NG2+ and $\mathrm{A}_{2} \mathrm{~B}_{5}{ }^{+}$cells behaved indistinguishably in terms of GFAP expression. Low percentages of $\mathrm{A}_{2} \mathrm{~B}_{5}$ and $\mathrm{NG}_{2}{ }^{+}$cells expressed GFAP after 4 or $5 \mathrm{~d}$ in serum-free medium (approximately $10-15 \%$ compared with $80-90 \%$ in serum). In contrast, although both the $\mathrm{NG}^{+}{ }^{+} \mathrm{GC}^{+}$and $\mathrm{A}_{2} \mathrm{~B}_{5}{ }^{+} \mathrm{GC}^{+}$phenotypes were seen more frequently after 4-5 $d$ in the absence of serum, the $\mathrm{A}_{2} \mathrm{~B}_{5}{ }^{+} \mathrm{GC}^{+}$phenotype was more common than the $\mathrm{NG}^{+} \mathrm{GC}^{+}$phenotype (55-60\% compared to $35-40 \%$ ). In making this comparison, it was very important to be able to start our experiments with a population of cells that had been depleted of $\mathrm{GC}^{+}$cells (to a level of roughly $5 \%$ ) by complementmediated lysis. In the absence of this depletion, we commonly found that $25-30 \%$ of the cells in the $\mathrm{A}_{2} \mathrm{~B}_{5}$-panned population were $\mathrm{GC}^{+}$. The ability to begin with a population containing $5 \%$ $\mathrm{GC}^{+}$cells rather than $30 \%$ gave us much more confidence in the relative increases in the $\mathrm{A}_{2} \mathrm{~B}_{5}{ }^{+} \mathrm{GC}^{+}$and $\mathrm{NG}_{2}{ }^{+} \mathrm{GC}^{+}$phenotypes observed in serum-free medium. The fact that $\mathrm{NG}^{+} \mathrm{GC}^{+}$ cells were outnumbered by $\mathrm{A}_{2} \mathrm{~B}_{5}{ }^{+} \mathrm{GC}^{+}$cells appears to be due to a fairly rapid loss of the NG2 marker from developing oli-

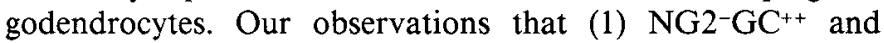
$\mathrm{NG} 2 \pm \mathrm{GC}^{+}$cells in the serum-free cultures were more brightly stained with anti-GC antibody than were $\mathrm{NG}^{+} \mathrm{GC}^{+}$cells and (2) $\mathrm{NG}^{+} \mathrm{GC}^{-}$cells were more brightly stained with anti-NG2 antibody than were $\mathrm{NG}_{2} \mathrm{GC}^{+}$cells are consistent with the idea that the $\mathrm{NG}^{+} \mathrm{GC}^{+}$phenotype is a transient intermediate. Furthermore, the decline in the percentage of stellate cells that express NG 2 from almost $90 \%$ on day 2 to $<40 \%$ on day 5 , provides a clear illustration of the loss of NG2 in the absence of serum (Table 1). This is similar to the observation of Raff et al. (1983b) that $\mathrm{A}_{2} \mathrm{~B}_{5}$ is lost over a period of time from $\mathrm{GC}^{+}$ cells. Loss of NG2 seems to occur more quickly, however, so that the $\mathrm{NG}_{2}{ }^{+} \mathrm{GC}^{+}$phenotype is more transient than $\mathrm{A}_{2} \mathrm{~B}_{5}{ }^{+} \mathrm{GC}^{+}$. It is clear that the $\mathrm{NG}^{2}{ }^{+} \mathrm{GC}^{+}$cells and the subsequent $\mathrm{NG}^{-} \mathrm{GC}^{++}$ cells that appeared in these cultures must have arisen from $\mathrm{NG}_{2}{ }^{+} \mathrm{GC}^{-}$, rather than $\mathrm{NG}^{-} \mathrm{GC}^{+}$, precursors, since the latter phenotype was not present in significant quantity in the purified starting population.

In summary, the bipotential glial precursor cells of the rat optic nerve expressed both the $A_{2} B_{5}$ and NG2 markers. When cultured in fetal calf serum, these cells continued to express both of these surface markers and, in addition, acquired the astrocytespecific GFAP marker. When maintained in serum-free medium, these cells did not express GFAP, but instead acquired the oligodendrocyte-specific GC marker. NG2 and GC were only transiently coexpressed, so that fully developed oligodendrocytes were negative for NG2. These results strengthen our previous perception that NG2 is expressed by a class of cells that are not terminally differentiated and can develop along more than one lineage pathway (Stallcup, 1981; Levine and Stallcup, 1987).

The behavior of the NG2 ${ }^{+} \mathrm{A}_{2} \mathrm{~B}_{5}{ }^{+}$optic nerve cells in serumcontaining medium is entirely consistent with the behavior of $\mathrm{NG} 2{ }^{+} \mathrm{A}_{2} \mathrm{~B}_{5}{ }^{+}$cells in serum-containing cultures of cerebellum (Levine and Stallcup, 1987). In both cases the precursor cells develop into type II astrocytes. However, $\mathrm{NG}^{+} \mathrm{A}_{2} \mathrm{~B}_{5}{ }^{+}$optic nerve cells maintained in serum-free medium appear to behave differently from the NG2 ${ }^{+} \mathrm{A}_{2} \mathrm{~B}_{5}{ }^{+}$cells we have studied in serumfree cerebellar cultures. Whereas up to $40 \%$ of optic nerve NG2 ${ }^{+}$ cells become $\mathrm{GC}^{+}$in the absence of serum, we have never observed a significant number of cerebellar $\mathrm{NG}^{+}$cells that express $\mathrm{GC}(<5 \%)$. Cerebellar NG2 ${ }^{+}$cells in scrum-frec medium express neither GC nor GFAP, and in this respect, they resemble smooth protoplasmic astrocytes, which may be a third member of the oligodendrocyte-type II astrocyte (O-2A) lineage (Levine and Stallcup, 1987).

Our results with cerebellar cultures would seem to be at odds with previously published reports by Williams et al. (1985) and Levi et al. (1986) that $A_{2} B_{s}^{\prime}$ cells in serum-free cultures of embryonic brain and cerebellum, respectively, acquire the GC marker. It might be argued that this discrepancy can be explained by our finding that NG2 continues to be expressed for only a short period of time by optic nerve cells once they are placed in serum-free medium and begin to acquire the properties of oligodendrocytes. If expression of NG2 by cerebellar cells also is transient in serum-free medium, it is possible that we may have missed seeing cells with an $\mathrm{NG}^{2}{ }^{+} \mathrm{GC}^{+}$phenotype. This possibility seems unlikely for the following reason. NG2 expression by stellate cells in cerebellar cultures is actually much more stable in serum-free medium than in serum-containing medium, so that $\mathrm{NG}_{2} \mathrm{GC}^{+}$cells should be easily detectable in the absence of serum (Levine and Stallcup, 1987). This is in contrast to the situation that exists in our optic nerve cultures, where NG2 expression is much more stable in the presence of serum. An alternative explanation that could account for our failure to observe many $\mathrm{NG}_{2}{ }^{+} \mathrm{GC}^{+}$cells in cerebellar cultures is based on the observation that in serum-free medium type I astrocytes are able to promote the proliferation of bipotential glial precursor cells and delay their differentiation into oligo- 

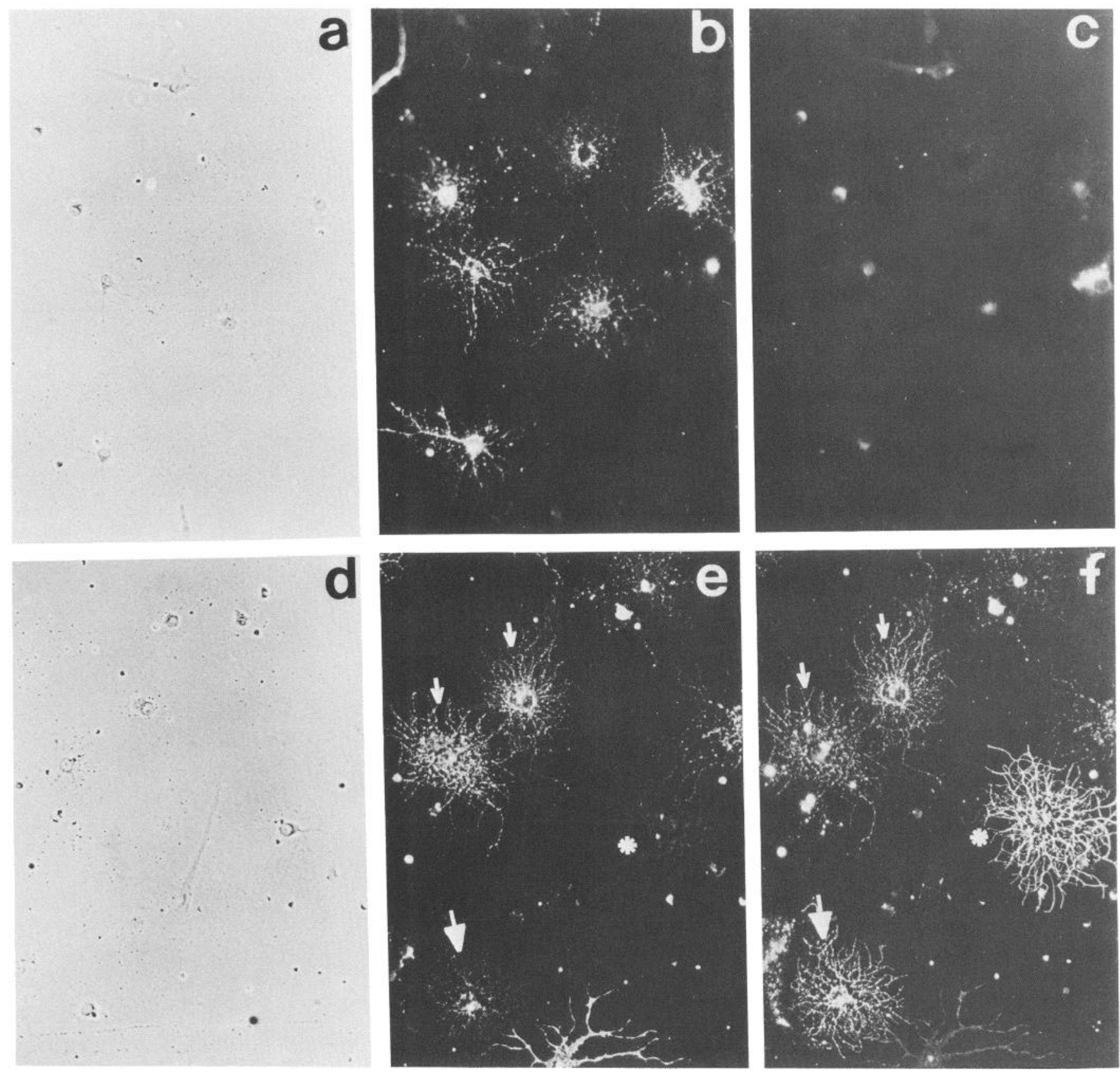

Figure 4. Phenotype of NG2-positive cells grown in serum-free medium. Purified optic nerve cultures were maintained in defined medium for 4 $\mathrm{d}$ and then double-labeled with anti-NG2 and anti-GFAP $(a-c)$ or anti-NG2 and anti-GC $(d-f)$. These cells do not acquire GFAP, but many express GC in a transient fashion. Note the difference in morphology from Figure 3. $a$, Phase contrast; $b$, anti-NG2 (rhodamine optics); $c$, anti-GFAP (fluorescein optics); $d$, phase contrast; $e$, anti-NG2 (rhodamine optics); $f$, anti-GC (fluorescein optics). In $e$ and $f$, small arrows denote cells that are positive for both NG2 and GC, the large arrow identifies a cell that is positive for GC and only weakly labeled with anti-NG2, and the asterisk marks a cell that is $\mathrm{GC}^{+}, \mathrm{NG}^{-}$.

dendrocytes (Noble and Murray, 1984; Raff et al., 1985). Since our cerebellar cultures typically contain many type I astrocytes, it is possible that in the absence of serum relatively few NG2+ precursor cells leave the proliferative cycle and differentiate into oligodendrocytes. This would explain the continued presence of numerous $\mathrm{NG}^{2}{ }^{+} \mathrm{GC}^{-}$cells in serum-free cerebellar cultures. Obviously, the resolution of these hypotheses will require further experimentation, perhaps utilizing the cell-panning technique to prepare cerebellar cultures depleted of type I astrocytes. For the present, the possibility remains that $\mathrm{NG}^{+}$cells in different parts of the nervous system may be able to differentiate along different lineage pathways. The local environment at these different sites would be a key factor in determining the developmental fate of these cells.

\section{References}

Bignami, A., L. Eng, D. Dahl, and C. Uyeda (1972) Localization of the glial fibrillary acidic protein in astrocytes by immunofluorescence. Brain Res. 43: 429-435.

Bottenstein, J., and G. Sato (1979) Growth of a rat neuroblastoma cell line in serum-free supplemented medium. Proc. Natl. Acad. Sci. USA 76: 514-517.

Danielsen, M., D. Peterson, and M. Stallcup (1983) Immunological 
selection of variant mouse lymphoid cells with altered glucocorticoid responsiveness. Mol. Cell. Biol. 3: 1310-1316.

Eisenbarth, G., F. Walsh, and M. Nirenberg (1979) Monoclonal antibody to a plasma membrane antigen of neurons. Proc. Natl. Acad. Sci. USA 76: 4913-4917.

Hubbard, A., and Z. Cohn (1972) The enzymatic iodination of the red cell membrane. J. Cell Biol. 55: 390-405.

Kasai, N., and R. Yu (1983) The monoclonal antibody $A_{2} B_{5}$ is specific to ganglioside $\mathrm{G}_{\mathrm{Qlc}}$. Brain Res. 277: 155-158.

Kundu, S., M. Pleatman, W. Redwine, A. Boyd, and D. Marcus (1983) Binding of monoclonal antibody $\mathrm{A}_{2} \mathrm{~B}_{5}$ to gangliosides. Biochem. Biophys. Res. Commun. 116: 836-842.

Laemmli, U. (1970) Cleavage of structural proteins during the assembly of the head of the bacteriophage T4. Nature 227: 680-685.

Levi, G., V. Gallo, and M. Ciotti (1986) Bipotential precursors of putative fibrous astrocytes and oligodendrocytes in rat cerebellar cultures express distinct surface features and "neuron-like" $\gamma$-amino butyric acid transport. Proc. Natl. Acad. Sci. USA 83: 1504-1508.

Levine, J., and P. Card (1987) Light and electron microscopic localization of a cell surface antigen (NG2) in the rat cerebellum: Association with smooth protoplasmic astrocytes. J. Neurosci. 7: 27112720.

Levine, J., and W. Stallcup (1987) Plasticity of developing cerebellar cells in vitro studied with antibodies against the NG2 antigen. J. Neurosci. 7: 2721-2731.

Miller, R., and M. Raff (1984) Fibrous and protoplasmic astrocytes are biochemically and developmentally distinct. J. Neurosci. 4: 585592.

Noble, M., and K. Murray (1984) Purified astrocytes promote the in vitro division of a bipotential glial progenitor cell. EMBO J. 3: 22432247.

Raff, M., R. Mirsky, K. Fields, R. Lisak, S. Dorfman, D. Silberberg, N.
Gregson, S. Leibowitz, and M. Kennedy (1978) Galactocerebroside is a specific antigenic marker for oligodendrocytes in culture. Nature 277: 813-816.

Raff, M., E. Abney, J. Cohen, R. Lindsay, and M. Noble (1983a) Two types of astrocytes in cultures of developing rat white matter: Differences in morphology, surface gangliosides, and growth characteristics. J. Neurosci. 3: 1289-1300.

Raff, M., R. Miller, and M. Noble (1983b) A glial progenitor cell that develops in vitro into an astrocyte or an oligodendrocyte depending on culture medium. Nature 303: 390-396.

Raff, M., B. Williams, and R. Miller (1984) The in vitro differentiation of a bipotential glial progenilor cell. EMBO J. 3: 1857-1864.

Raff, M., E. Abney, and J. Fok-Seang (1985) Reconstitution of a developmental clock in vitro: A critical role for astrocytes in the timing of oligodendrocyte differentiation. Cell 42: 61-69.

Schubert, D., S. Heinemann, W. Carlisle, H. Tarikas, B. Kimes, J. Patrick, J. Steinbach, W. Culp, and B. Brandt (1974) Clonal cell lines from the rat central nervous system. Nature 249: 224-227.

Stallcup, W. (1981) The NG2 antigen, a putative lineage marker: Immunofluorescent localization in primary cultures of rat brain. Dev. Biol. 83: 154-165.

Stallcup, W., L. Beasley, and J. Levine (1984) Cell-surface molecules that characterize different stages in the development of cerebellar interneurons. Cold Spring Harbor Symp. Quant. Biol. (Dev. Neurobiol.) 48: 761-774.

Williams, B., E. Abney, and M. Raff (1985) Macroglial cell development in embryonic rat brain: Studies using monoclonal antibodies, fluorescence-activated cell sorting, and cell culture. Dev. Biol. 112: 126-134.

Wilson, S., E. Baetge, and W. Stallcup (1981) Antisera specific for cell lines with mixed neuronal and glial properties. Dev. Biol. 83: 146153. 